\title{
Prevalence of vitamin D deficiency in Indian women
}

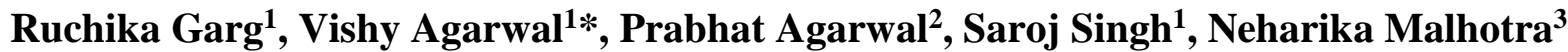

\author{
${ }^{1}$ Department of Obstetrics and Gynaecology, ${ }^{2}$ Department of Medicine, Sarojini Naidu Medical College, Agra, Uttar \\ Pradesh, India \\ ${ }^{3}$ Rainbow IVF, Agra, Uttar Pradesh, India
}

Received: 06 March 2018

Revised: 17 April 2018

Accepted: 30 April 2018

\author{
*Correspondence: \\ Dr. Vishy Agarwal, \\ E-mail: vishy14agarwal@gmail.com
}

Copyright: (C) the author(s), publisher and licensee Medip Academy. This is an open-access article distributed under the terms of the Creative Commons Attribution Non-Commercial License, which permits unrestricted non-commercial use, distribution, and reproduction in any medium, provided the original work is properly cited.

\begin{abstract}
Background: Vitamin D is the widespread nutritional deficiency in India yet it has been widely undiagnosed and untreated. Nowadays its deficiency has become the widely investigational topic as the role of vitamin D deficiency has been identified in various disorders.

Methods: In order to study the prevalence of vitamin $d$ in our study (level $<20 \mathrm{ng} / \mathrm{ml}$ ) the 1052 women attending the clinic are taken into the consideration and the levels of vitamin $\mathrm{d}$ are done in them irrespective of the symptom.

Results: In our study the 1052 women attending the clinic were taken and it was found that the prevalence of vitamin D level $<20 \mathrm{ng} / \mathrm{ml}$ was $64.06 \%$ and the level of vitamin $\mathrm{D}<30 \mathrm{ng} / \mathrm{ml}$ was $98.75 \%$ and it was higher in younger $(65.51 \%)$, illiterate $(89.92 \%)$, housewife women $(70 \%)$ and its prevalence was higher in women residing in rural areas $(69.94 \%)$ and also having an income $<10,000(61.96 \%)$.

Conclusions: Thus it was concluded the cut off level for the vitamin D deficiency level should be revised in according to the need of the people of India as the high prevalence of vitamin D deficiency in our study could be the result of our being over concerned and the internationally set up criteria for its deficiency and also ICMR should also revise the recommend daily allowance to include daily recommendation of vitamin D level.
\end{abstract}

Keywords: Indian women, Prevalence, Vitamin D

\section{INTRODUCTION}

Vitamin D is the widespread nutritional deficiency in India yet it has been widely undiagnosed and untreated. Its deficiency affected the individual irrespective of the gender, age, sex, race and geography.

Nowadays vitamin D deficiency has become the widely investigational topic as the role of vitamin D deficiency has been identified in various disorders besides its worldwide known skeletal side effects. Chronic vitamin $\mathrm{D}$ deficiency in adults results in osteomalacia, osteoporosis, muscle weakness. ${ }^{1-7}$ Recent researches had also linked vitamin D deficiency with the increased risk of developing tuberculosis, otitis media, upper respiratory tract infections and influenza and many other infections. ${ }^{8-}$

${ }^{12}$ Its deficiency has also linked with the increased risk of developing hypertension, diabetes, obesity and high triglyceride level ultimately leading to increased risk of cardiovascular mortality. ${ }^{13}$ Researchers have shown epidemiological association of vitamin D deficiency and type 1 diabetes. ${ }^{14}$ A meta-analysis of observational studies showed a $30 \%$ reduction in risk of type 1 diabetes mellitus in children receiving vitamin D supplements. ${ }^{15}$

In India, the cultural and social taboos affect the lifestyle of the individuals. Most of the people of the country are pure vegetarians and the others are underprivileged. 
These two factors affect the nutritional status leading to the vitamin deficiency in the individuals. Also, the clothing of the individuals will limit the sun exposure and ultimately aggravating the vitamin D deficiency.

Additionally, vitamin D deficiency supplements are available but most Indians were unaware about their requirement of vitamin $\mathrm{D}$.

Plasma 25(OH)D or calcidiol (a summation of $\mathrm{D}_{3}$ and $\mathrm{D}_{2}$ forms) is the most reliable marker of vitamin D status. Immunoassays such as radioimmunoassay (RIA), enzyme linked immunosorbant assay (ELISA), chemiluminescence immunoassay and protein binding assays are used in routine testing of $25(\mathrm{OH}) \mathrm{D}$ in clinical laboratories. LCTMS (liquid chromatography tandem mass spectrometry) is the widely accepted reference method for $25(\mathrm{OH}) \mathrm{D}$ measurement. However, LCTMS is tedious, expensive and time consuming and therefore seldom used commercially.

Since vitamin D undernutrition is largely silent and subclincal, the indication for testing remains controversial. At present $25(\mathrm{OH}) \mathrm{D}$ test is the "most ordered test" in the USA. A similar trend has just begun in the upper socioeconomic stratum in India too.

Thus the aim of this paper is to encounter the gravity of the vitamin D deficiency problem throughout India so that the physicians take necessary caution and care in the diagnosis and treatment of Vitamin D deficiency.

But it is important to note that the studies which have reported an increased prevalence of vitamin D deficiency in India have taken the cut-off limits of approximately 20 $\mathrm{ng} / \mathrm{ml}$ for severe vitamin $\mathrm{D}$ deficiency, cut-off limits of $30 \mathrm{ng} / \mathrm{ml}$ for moderate vitamin D deficiency, and a cutoff limit of $<35 \mathrm{ng} / \mathrm{ml}$ as mild deficiency.

\section{METHODS}

In order to study the prevalence of vitamin $\mathrm{D}$ deficiency in our study the level of vitamin D are done in 1052 women attending the Gynae clinic over the period of 6 months from September 2017 to Januarary 2018 irrespective of the clinical features by the method of electrochemiluminescence.

Detailed history and examination were performed with special regard to socioeconomic status,clinical features suggestive of osteomalacia (e.g. proximal muscle weakness, bone pain,tenderness or fractures ) or past rickets.

Daily intake of dietary calcium and vitamin D was calculated from a food frequency questionnaire. Any supplement intake was also noted. Daily sun exposure was assessed by taking a detailed history of the daily routine separately during summer and winter seasons and of the type of clothing worn.
Sunshine exposure was calculated as hours of exposure/day X\% of body surface area exposed.

\section{Inclusion criteria}

Inclusion criteria were age 15-60 yrs; all women attending the Gynaec clinic.

\section{Exclusion criteria}

Exclusion criteria were age $>15$ yrs or $<60$ yrs; women with parathrome hormone (PTH) deficiency; women with premature ovarian failure; women with chronic liver disease; women with renal disease; women on antitubercular or antiepileptic treatment in the previous 3 months.

\section{RESULTS}

In the present study 1052 women attending the clinic were taken for the consideration and the vitamin D level were done in them. Table 1 shows that the prevalence of vitamin D deficiency (level $<20 \mathrm{ng} / \mathrm{ml}$ ) was $65.51 \%$ among women with age $<30$ years and it was $61.83 \%$ among women with age $>30$ years.

It also shows that the prevalence of vitamin D deficiency was $89.92 \%$ among illiterate women and it was $43.9 \%$ among literate women. Prevalence of vitamin D deficiency was $70 \%$ among housewife women and $40.56 \%$ among working women.

It also shows that the prevalence of vitamin D deficiency was $69.94 \%$ among rural women, $61.96 \%$ among women with income $<10,000$ and it was $57.72 \%, 46.99 \%$ among urban women and women with income $>10,000$ respectively.

Table 1: Distribution of patients according to age, education, category, housing and income.

\begin{tabular}{|lll|}
\hline Parameter & $\begin{array}{l}\text { Total number } \\
\text { of patients }\end{array}$ & $\begin{array}{l}\text { No. of patients } \\
\text { with vitamin D } \\
<20 \mathrm{ng} / \mathrm{ml}(\%)\end{array}$ \\
\hline Age $<30$ & 638 & $418(65.51)$ \\
\hline$>30$ & 414 & $256(61.83)$ \\
\hline Education & & \\
\hline Illiterate & 462 & $415(89.92)$ \\
\hline Literate & 590 & $259(43.9)$ \\
\hline Category & & \\
\hline Housewife & 840 & $588(70)$ \\
\hline Working & 212 & $86(40.56)$ \\
\hline Housing & & \\
\hline Rural & 560 & $390(69.64)$ \\
\hline Urban & 492 & $284(57.72)$ \\
\hline Income & & $363(61.96)$ \\
\hline$<10,000$ & 586 & $311(46.99)$ \\
\hline$>10,000$ & 466 &
\end{tabular}


Table 2: Distribution of patients according to exposure of sun and usage of vitamin D supplements.

\begin{tabular}{|lll|}
\hline Parameter & $\begin{array}{l}\text { Total no. of } \\
\text { patients }\end{array}$ & $\begin{array}{l}\text { No. of patients } \\
\text { With vitamin D } \\
<20(\%)\end{array}$ \\
\hline Exposure to sun & & \\
\hline More & 498 & $258(51.80)$ \\
\hline Less & 554 & $416(75.09 \%)$ \\
\hline Supplements & & \\
\hline Yes & 232 & $104(44.8)$ \\
\hline No & 820 & $570(69.51)$ \\
\hline
\end{tabular}

Table 3: Distribution of patients according to vitamin D levels.

\begin{tabular}{|l|l|l|}
\hline Vitamin D level $(\mathrm{ng} / \mathrm{ml})$ & No. of patients & Percentage \\
\hline$<20$ & 674 & 64.06 \\
\hline $20-30$ & 365 & 34.69 \\
\hline$>30$ & 13 & 1.23 \\
\hline
\end{tabular}

Table 2 shows that the prevalence of vitamin D deficiency with more exposure to sun was $51.80 \%$ with more exposure to sun and it was $75.09 \%$ among women with less sunlight exposure. It also shows that the prevalence of vitamin D deficiency among women using and not using the vitamin D supplements was $44.8 \%$ and $69.51 \%$ respectively Table 3 shows that the prevalence of Indian women with vitamin D level $<20 \mathrm{ng} / \mathrm{ml}$ was $64.06 \%$, women with levels between was $20-30 \mathrm{ng} / \mathrm{ml}$ was $34.69 \%$ and women with $>30 \mathrm{ng} / \mathrm{ml}$.

\section{DISCUSSION}

In the present study it was shown that the prevalence of vitamin D deficiency was higher among younger, illiterate women. It was also higher among women residing the rural areas, and women those are housewife and also having income $<10,000$.

It was found in the present study that the prevalence of vitamin D level $<20 \mathrm{ng} / \mathrm{ml}$ in the Indian women was $64.06 \%$ and the prevalence of vitamin D level $<30 \mathrm{ng} / \mathrm{ml}$ in Indian women was $98.75 \%$. This is in accordance to the study conducted by Kritiar et al in Medanta, Gurgaon in which $25(\mathrm{OH})$ vit $\mathrm{D}$ deficiency was $93 \%$ and out of which $34 \%$ subjects were $25(\mathrm{OH})$ vit D insufficient and $59 \%$ had frank deficiency and also in accordance to the study in Ballabgarh district in which the prevalence of Vitamin D deficiency (levels $<20 \mathrm{ng} / \mathrm{ml}$ ) was found in $90.8 \%$. Of the 381 , only one individual was found to have vitamin D sufficiency. ${ }^{16}$

As per the report of International Osteoporosis Foundation, in North India, $96 \%$ of noenates, $91 \%$ of healthy school girls, $78 \%$ of healthy hospital staff, and $84 \%$ of pregnant women were found to have hypovitaminosis D. On the other hand, prevalence of vitamin D deficiency in southern India was estimated to be $40 \%$ among males and $70 \%$ among females. There was also a significant rural urban variation in the vitamin $\mathrm{D}$ deficiency status that was attributed to the diversity of occupation which the people were involved in. ${ }^{17}$

Tandon et al shows that the mean vitamin D levels of the study population was $26.86 \mathrm{ng} / \mathrm{ml}$ and mean fasting blood glucose levels was $134.52 \pm 17.56 \mathrm{mg} \%$. While evaluating the vitamin D status of the study population, $53.35 \%$ of the population has vitamin D deficiency, $19.48 \%$ had insufficiency and $26.83 \%$ had adequate vitamin D levels. $^{18}$

Sachan et al had studied the 207 pregnant women from the Queen Mary Hospital, King George Medical University Lucknow for the maternal vitamin $25(\mathrm{OH}) \mathrm{D}$ level along with the cord blood vitamin $25(\mathrm{OH}) \mathrm{D}$ levels in the neonates. The result of the study was that the $42.5 \%$ of the women had the vitamin D level was $<10$ $\mathrm{ng} / \mathrm{ml}$ and about $66.7 \%$ of the women had the vitamin D level was $<15 \mathrm{ng} / \mathrm{ml}$. Follow up had shown that the cord blood 25(OH)D levels was significantly lower $(5.2 \pm 3$ and $11.8 \pm 5 \mathrm{ng} / \mathrm{ml})$ respectively in women with $25(\mathrm{OH}) \mathrm{D}$ concentration was $<10 \mathrm{ng} / \mathrm{ml}$ than in mother with $25(\mathrm{OH}) \mathrm{D}$ concentration $>10 \mathrm{ng} / \mathrm{ml}^{19}$

Goswami et al showed that despite of abundant sunlight, healthy persons in Delhi remained vitamin D deficient. This may be because of skin pigmentation, inadequate direct sun exposure as well as low-calcium, high-phytate diets, pregnancy, and winter-related reduced sunlight exposure which may affect vitamin D levels. ${ }^{20}$

Use of sunscreen could be one of the factors that affect vitamin D level. Few authors have reported that sunscreens block the cutaneous absorption of UV-B radiation and prevent sunburn and thus decreases the vitamin D stores. $^{21}$

Matsuka et al showed that the long-term use of sunscreens may be associated with low body stores of vitamin $\mathrm{D}$ in some persons. $^{22}$

\section{CONCLUSION}

Vitamin D deficiency prevails in epidemic proportions all over the Indian subcontinent with the prevalence of 70 $100 \%$ in the general population. The widespread deficiency of vitamin D deficiency in India could be because of the dietary intake, high fibre and phytate intake that will decrease the vitamin D levels.

Thus, it was concluded that to reduce the prevalence of Vitamin D deficiency in India it is very important that the public and private sector work very closely with each other such as the cut off level for the vitamin D deficiency level should be revised in according to the need of the people of India as the high prevalence of vitamin $\mathrm{D}$ deficiency in our study could be the result of 
our being over concerned and the internationally set up criteria for its deficiency.

Also, ICMR should also revise the recommend daily allowance to include daily recommendation of vitamin D level. Government of India should organize programs to increase public awareness of vitamin D deficiency, causes and long term consequences. Daily physical activity in the sunshine should be included in the social curriculum and also the Government of India should take steps for the fortification of staple food with the vitamin $\mathrm{D}$ and also make an effort so that the vitamin D supplements should be available at the affordable costs.

\section{Funding: No funding sources}

Conflict of interest: None declared

Ethical approval: The study was approved by the Institutional Ethics Committee

\section{REFERENCES}

1. Hazell TJ, DeGuire JR, Weiler HA. Vitamin D: An overview of its role in skeletal muscle physiology in children and adolescents. Nutr Rev. 2012;70:520-33.

2. Holick MF. The role of vitamin D for bone health and fracture prevention. Curr. Osteoporos. Rep. 2006;4:96102.

3. Lips P, van Schoor NM. The effect of vitamin D on bone and osteoporosis. Best Pract Res Clin Endocrinol Metab. 2011;25:585-91.

4. Janssen HC, Samson MM, Verhaar HJ. Vitamin D deficiency, muscle function, and falls in elderly people. Am J Clin Nutr. 2002;75:611-5.

5. Bischoff HA, Stahelin HB, Urscheler N, Ehrsam R, Vonthein R, Perrig-Chiello P. Muscle strength in the elderly: Its relation to vitamin D metabolites. Arch Phys Med Rehabil. 1999;80:54-8.

6. Bischoff-Ferrari HA, Dawson-Hughes B, Willett WC, Staehelin HB, Bazemore MG, Zee RY, et al. Effect of Vitamin D on falls: A meta-analysis. JAMA. 2004;291:1999-2006.

7. Bischoff-Ferrari HA, Dietrich T, Orav EJ, DawsonHughes B. Positive association between 25-hydroxy vitamin D levels and bone mineral density: A population-based study of younger and older adults. Am J Med. 2004;116:634-9.

8. Nnoaham KE, Clarke A. Low serum vitamin D levels and tuberculosis: A systematic review and metaanalysis. Int J Epidemiol. 2008;37:113-9.

9. Martineau AR. Old wine in new bottles: Vitamin D in the treatment and prevention of tuberculosis. Proc Nutr Soc. 2012;71:84-9.

10. Linday LA, Shindledecker RD, Dolitsky JN, Chen TC, Holick MF. Plasma 25-hydroxyvitamin D levels in young children undergoing placement of tympanostomy tubes. Ann Otol Rhinol Laryngol. 2008;117:740-4.
11. Ginde AA, Mansbach JM, Camargo CA Jr. Association between serum 25-hydroxyvitamin $\mathrm{D}$ level and upper respiratory tract infection in the Third National Health and Nutrition Examination Survey. Arch Intern Med. 2009;169:384-90.

12. Cannell JJ, Vieth R, Umhau JC, Holick MF, Grant WB, Madronich S, et al. Epidemic influenza and vitamin D. Epidemiol Infect. 2006;134:1129-40.

13. Martins D, Wolf M, Pan D, Zadshir A, Tareen N, Thadhani R, et al. Prevalence of cardiovascular risk factors and the serum levels of 25-hydroxyvitamin D in the United States: Data from the Third National Health and Nutrition Examination Survey. Arch Intern Med. 2007;167:1159-65.

14. Hypponen E, Laara E, Reunanen A, Jarvelin MR, Virtanen SM. Intake of vitamin D and risk of type 1 diabetes: A birth-cohort study. Lancet. 2001;358:15003.

15. Zipitis CS, Akobeng AK. Vitamin D supplementation in early childhood and risk of type 1 diabetes: A systematic review and meta-analysis. Arch Dis Child. 2008;93:512-7.

16. Shukla K, Sharma S, Gupta A, Raizada A, Vinayak K. Current Scenario of Prevalence Of Vitamin D deficiency Ostensibly Healthy Indian Population.A Hospital based Retrospective Study. Indian J Clin Biochem. 2016;31(4):452-7.

17. Mithal A, Wahl DA, Bonjour JP, Burckhardt P, Dawson - Hughes B, Eisman JA, et al. IOF Committee of Scientific Advisors (CSA) Nutrition Working Group. Global vitamin D status and determinants of hypovitaminosis D. Osteoporos Int 2009;20:1807-20.

18. Tandon VR, Sharma S, Mahajan S, Raina K, Mahajan A, Khajuria V, et al. Prevalence of Vitamin D deficiency among Indian menopausal women and its correlation with diabetes. A first Indian cross sectional data. 2014;5(3):121-5.

19. Sachan A, Gupta R, Das V, Agarwal A, Awasthi PK, Bhatia V, et al. High prevalence of vitamin D deficiency among pregnant women and their newborn in northern India. Am J Clin Nutr. 2005;81:1060-4.

20. Goswami R, Gupta N, Goswami D, Marwaha RK, Tandon N, Kochupilli N. Prevalence and significance of low 25-hydroxyvitamin D concentrations in healthy subjects in Delhi. Am J Clin Nutr. 2000;72:472-5.

21. Clemens TL, Adams JS, Henderson SL, Holick MF. Increased skin pigment reduces the capacity of skin to synthesise vitamin D3. Lancet. 1982;1:74-76.

22. Matsuoka LY, Wortsman J, Haddad JG, Kolm P, Hollis BW. Racial pigmentation and the cutaneous synthesis of vitamin D. Arch Dermatol. 1991;127:536-8.

Cite this article as: Garg R, Agarwal V, Agarwal P, Singh S, Malhotra N. Prevalence of vitamin D deficiency in Indian women. Int J Reprod Contracept Obstet Gynecol 2018;7:2222-5. 